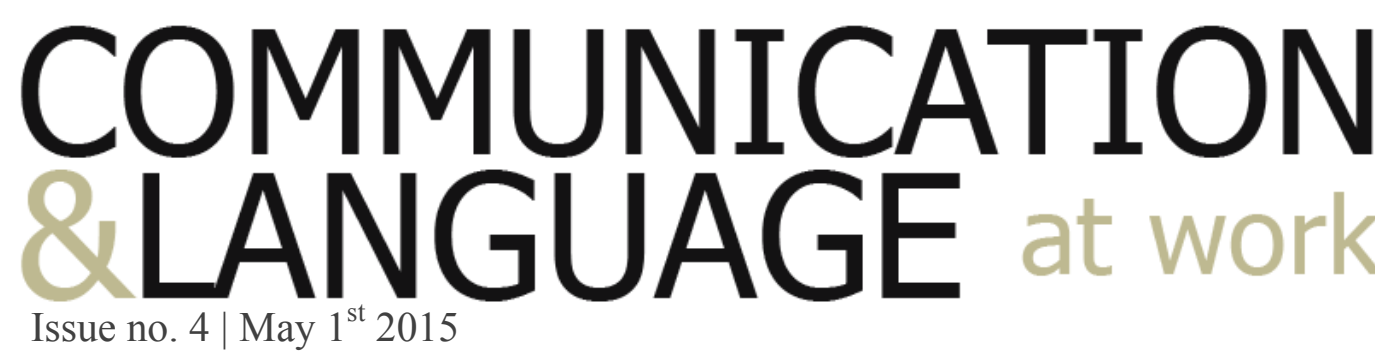

Issue no. 4 | May $1^{\text {st }} 2015$

\title{
Impression management as symbolic capital: an intercultural comparison of presentations by CEOs on social network sites \\ Klarissa Lueg \& Camilla Nielsen
}

$(88-120)$

\section{Article URL:}

http://ojs.statsbiblioteket.dk/index.php/claw/article/view/20774

Subscribe:

http://ojs.statsbiblioteket.dk/index.php/claw/notification/subscribeMailList

Archives:

http://ojs.statsbiblioteket.dk/index.php/claw/issue/archive

\section{Publishing:}

http://ojs.statsbiblioteket.dk/index.php/claw/about/submissions\#onlineSubmissions

\section{Contact:}

http://ojs.statsbiblioteket.dk/index.php/claw/about/contact

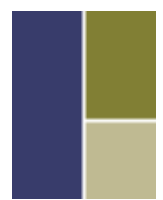

| Bridging Theory and Practice |

http://ojs.statsbiblioteket.dk/index.php/claw 
Communication \& Language at Work

\title{
Impression management as symbolic capital
}

An intercultural comparison of presentations by CEOs on social

network sites

Klarissa Lueg

Assistant Professor, $\mathrm{PhD}$

Department of Business Communication, Aarhus University

\section{Camilla Nielsen}

Post Graduate

Department of Business Communication, Aarhus University

\begin{abstract}
Social Network Sites (SNS) play an increasingly important role in the European business world, especially with respect to cross-cultural impression management. Departing from the Bourdieusian concept of "capital," this paper analyzes the differences in the use of two popular business SNS: XING in Germany and LinkedIn in Denmark. We summarize those differences and relate them to different cultural contexts and impression management practices. Our sample consists of Danish Higher Executives (HEs)/managers (e.g., CEOs) and companies that have profiles on both SNS, thus reaching out to both the German and the Danish markets. It is apparent that even business experts operating in both markets could better adapt to the standards and possibilities offered by the German SNS with respect to impression management. We introduce a set of recommendations to foster SNS-related and culture-sensitive impression management.
\end{abstract}




\section{Impression management as symbolic capital: an intercultural comparison of presentations by CEOs on social network sites}

\section{Introduction}

The confident handling of personal and company profiles on Social Network Sites (SNS) has become a key factor in business communication. Successful impression management by CEOs can have a direct, beneficial impact on a company's image (Pollach and Kerbler 2011). A Danish survey shows that 74\% of Danish companies surveyed use SNS for marketing or sales promotion purposes (Danmarks_Statistik 2013). The tendency to use SNS, particularly international SNS, might be lower in Denmark's most important export partner (Udenrigsministeriet 2014), Germany: 24\% of specialists and executive staff use XING for marketing purposes (SID/FIT $2010: 5$ ). Dwyer (2007: 5) claims that impression management is essential for SNS because they allow people to present themselves as who they "like to be." Despite the rise of the international SNS LinkedIn, the SNS XING is still frequently used in Germany. In contrast, Denmark does not have its own Danish-language SNS; thus, LinkedIn is dominant. We assume that in both countries, different sets of social practices related to impression management and the presentation of professional skills prevail. Thus, we pose the following research question: What are the differences between how Danish companies and Higher Executives (HEs) use XING and LinkedIn? Departing from the Bourdieusian concept of capital (Bourdieu 1997), we analyze and compare the company and personal-professional profiles of Danish managers on a German SNS (XING) and a Danish/international one (LinkedIn). Our findings indicate that although all HEs aim either to establish or to increase Danish-German business relations, German SNS profiles cannot accomplish these aims. We thus recommend that Danish HEs using XING to reach out to the German market make themselves aware of German social and cultural practices and adapt their SNS communication strategy accordingly.

Our paper is structured as follows. Section 2 establishes our theoretical background by introducing Bourdieusian theoretical concepts and providing an overview of the association between SNS and impression management. By doing so, we establish the 


\section{Communication \& Language at Work}

basis for the introduction of our research design in section 3 . We introduce our results in section 4 and discuss this study's contributions and limitations in section 5. Finally, our conclusion, which is found in section 6 , summarizes this study's outcome.

\section{Theoretical background}

\section{Bourdieusian Theory and Impression Management on SNS}

This article aims to compare impression management in different cultural contexts from a Bourdieusian perspective. Within this perspective, the concept of "capital" is crucial. The concept of capital is essentially composed of three different forms of capital: economic, cultural and social (Bourdieu 1983: 183ff). Economic capital is money, and social capital is the sum of network contacts and fruitful affiliations. Cultural capital can be subdivided into three types. The embodied form of cultural capital incorporates family heritage and covers competences and knowledge (Bourdieu 1997). The objectified form of cultural capital includes the possession of cultural goods (books, instruments). The institutionalized form of cultural capital displays its owner's knowledge through credentials, such as a diploma, from authorized institutions (Bourdieu 1997: 47). A fourth type of capital is symbolic capital, which consists of other types of capital recognized as legitimate (Bourdieu 2005: 195; Lueg 2011; Lueg and Lueg 2015). Symbolic capital corresponds with impression management under certain conditions, e.g., when strategically displayed. Each form of capital represents accumulated labor (Bourdieu 1983: 183) and renders the "games of society - not least, the economic game - something other than simple games of chance" (Bourdieu 1997). Under certain conditions, capital can be transferred into another form of capital (Bourdieu 1983: 195): in that way, cultural capital, which is composed of knowledge as embodied capital or a university degree as its institutionalized state, can be transferred into money when it fulfills the requirement of the labor market or one's chosen field (Bourdieu 1997). Thus, the assumption of the existence of cultural differences in what is considered symbolic capital-i.e., capital between different cultural spaces (e.g., nations, language spaces, countries) that is valuable overall (Vester 1996: 78) - is essential for this analysis. According to Bourdieu, the more definitive the knowledge of and the social correspondence (i.e., "doxa" (Bourdieu 1990: 68)) with such fields, the 


\section{C ommunication \& Language at Work}

better the chances of success are. The assumption that a culturally adequate presentation of cultural capital on SNS can be transferred through social capital (i.e., SNS contacts and clients) and, ultimately, economic capital is based on this notion. Bourdieu further proposes that agents from different social backgrounds are differently equipped with the capital that is considered legitimate (i.e., that is acknowledged) in a society. To him, the offspring of the higher classes are favorably predisposed to what society accepts and rewards as suitable and honorable (Bourdieu and Passeron 1977). The primary determinant of this study is not class, but culture, because we compare the SNS profiles of executives in two countries. We propose that different cultural frames require slightly adapted displays of capital to achieve acknowledgement and to have it "recognized as legitimate competence" (Bourdieu 1977: 49) in an SNS context. Despite the fact that the Bourdieusian concept of capital is an appropriate tool for exploring impression management, no study on impression management in SNS has employed all forms of capital. Although social capital has been employed to explore Facebook (Ellison, Steinfield et al. 2007; Stefanone, Kwon et al. 2011; Vitak and Ellison 2013) and concepts similar to Bourdieu's symbolic capital (e.g., signaling theory) have been applied to SNS (Donath and Boyd 2004), "research on participatory websites has been minimally theoretical and lacks a comprehensive framework" (Walther and Jang 2012: 2). A Bourdieusian perspective on impression management thus adds to the attempts to theorize and appropriately frame SNS research, especially when employed in a comparative cultural empirical context (for an extended literature review s. Nielsen 2014).

\section{SNS and Impression Management}

We chose the notion of SNS instead of other terms that either are more general (social media, Good 2013) or emphasize active networking, which although part of a network, might not always be users' focus (social networking sites, web sites, or service, Boyd and Heer 2006; Buffardi and Campbell 2008; Walther, Van Der Heide et al. 2009; Rosen, Lafontaine et al. 2011). We thus condone the idea that "while networking is possible on these sites, it is not the primary practice on many of them" (Boyd and Ellison 2007: 211). Instead, we focus on impression management as the dominant selfinitiated practice by SNS users. Boyd and Ellison define SNS as follows: "We define 


\section{C ommunication \& Language at Work}

social network sites as web-based services that allow individuals to (1) construct a public or semi-public profile within a bounded system, (2) articulate a list of other users with whom they share a connection, and (3) view and traverse their list of connections and those made by others within the system" (Boyd and Ellison 2007: 211) Both XING and LinkedIn, the SNS studied in this project, fulfill these criteria. Expanding the above definition's frame of reference, we include both people and companies as agents that intentionally use SNS.

SNS are ideal platforms for modern impression management (Cunningham 2013). According to Goffman (1976: 35), agents desire to control the impression that they make on others, partly by strategically idealizing that impression. Goffman points to the relevance of impression-management skills to work life: they might even determine career success. To make a good impression, agents strive to represent those values that are considered to be socially desirable (Goffman 1976: 35). Relating this intent back to our Bourdieusian theory frame, we hypothesize that agents benefit from an awareness of symbolic capital in the national and business contexts that they navigate. Because the objective of business SNS users is to gain more traffic and ultimately clients, they must provide their audience with an impression that shows them in a positive light. Thus, Danish executives and managers need to know what type of information is worth presenting when operating in two markets.

\section{Research Design}

\section{Sample}

Our sample consists of 17 Danish company pages and the profiles of their representatives (executive managers, HE) on both SNS. Our sample represents different lines of business and different company sizes (s. table 1). Most of the companies in the sample (14) are small and medium-sized companies with up to 200 employees. Only three companies can be classified as large companies with more than 200 employees. The sample was recruited on May 27, 2013. We chose our sample based on the following criteria. The eligibility criteria specified companies and managers present on both XING and LinkedIn, thus targeting a Danish/international and, more specifically, a German market. The companies' orientation toward the German market was required to 


\section{C ommunication \& Language at Work}

be further indicated through the display of a company profile in German. As conventional in the empirical social sciences, both the managers and the companies remain anonymous in this publication. We chose to replace the managers' names with letters $(\mathrm{A}, \mathrm{B}, \mathrm{C} \ldots)$ and the companies with corresponding numbers $(1,2,3 \ldots)$, indicating the relationship between the two. That is, manager A represents Company 1, and so forth. We analyze 68 profiles: 17 manager profiles on LinkedIn, 17 manager profiles on XING, 17 company profiles on XING and 17 company profiles on LinkedIn. However, due to the interconnectedness of these profiles, we discuss 17 units of analysis.

Table 1: The sample: lines of business and size of the companies as self-described and displayed on XING.

\begin{tabular}{|l|l|l|}
\hline Company & Line of Business & Size \\
\hline 1 & Computer Software & $1-10$ \\
\hline 2 & Computer Software & $11-50$ \\
\hline 3 & International Trade and Development & $11-50$ \\
\hline 4 & Legal Advice & $1-10$ \\
\hline 5 & Legal Advice & $201-500$ \\
\hline 6 & Mechanical Engineering & $201-500$ \\
\hline 7 & Internet & $11-50$ \\
\hline 8 & IT & $1-10$ \\
\hline 9 & Computer \& Network Security & $11-50$ \\
\hline 10 & Business Consulting & $1-10$ \\
\hline 11 & IT & $51-200$ \\
\hline 12 & Computer Software & $51-200$ \\
\hline 13 & Import/Export & $51-200$ \\
\hline 14 & IT & $11-50$ \\
\hline 15 & IT & $51-200$ \\
\hline 16 & Renewable Energy and Environment & 10.001 \\
\hline 17 & Telecommunications & $1-10$ \\
\hline
\end{tabular}

\section{Data Selection}

We retrieved our data from XING and LinkedIn. XING has approximately 14 million users (Xing 2013), and LinkedIn has approximately 225 million users (LinkedIn 2013). In some cases, data retrieval was only possible by connecting with the managers on their respective SNS. Doing so also enabled us to confirm that the choice of research subjects corresponded with our research intention. We did not encounter obstacles to retrieving company data: the profiles are open access because the researcher has user profiles on the SNS. We archived all data by saving screenshots. We collected data only 


\section{C ommunication \& Language at Work}

from selected categories that provide the potential for impression management and only from categories that are comparable on both SNS. We named the manager-profile categories professional experience, education, language ability, activities and interests, groups and organizations, recommendations and number of contacts, and we named the company-profile categories about us, (education and language ability), company size, number of employees represented on the SNS and number of subscribers.

\section{Analysis}

In accordance with the Bourdieusian tradition of combining a variety of methods (Kieserling 2008: 4), we conduct two comparative content analyses to identify differences in HEs' impression management strategies on XING versus LinkedIn. We conduct both a qualitative and a quantitative analysis and thus place ourselves in the tradition of combining quantitative and qualitative approaches (Mayring 1983; Mayring 2001) to "mixed methods" (Tashakkori 2009) and "comparative mixed methods" (Bernardi, Keim et al. 2007). Our choice of content analysis is motivated by the assumption that agents' writing expresses their beliefs, attitudes and knowledge (Mayntz, Holm et al. 1969: 151). The user-generated text provided on XING and LinkedIn thus provides a path to conclusions about the subjects' cultural knowledge or lack of knowledge in the given context. Content analysis is an appropriate tool for SNS research (Grasmuck, Martin et al. 2009). In principle, we base both our quantitative and our qualitative analysis on the same categories. The qualitative analysis is conducted subsequent to the quantitative analysis to ensure that new aspects or any discrepancies - e.g., eye-catching differences in the profiles of the same person on XING and LinkedIn - could be added and explored. Thus, our qualitative analysis asks how, instead of how often, a social phenomenon presents itself (Haas and Scheibelhofer 1998: 1).

\section{Choice of Indicators and Categories}

We determine indicators for our analysis of cultural and social capital (Früh 1991; Merten 1995: 317f). We choose different indicators for company and personalprofessional profiles. We search for indicators of the varying capital forms among the SNS' pre-defined categories. For the company profiles, we select education and 


\section{C ommunication \& Language at Work}

language abilities as indicators of cultural capital. In particular, we look for institutionalized cultural capital in the form of the company's certificates, accreditations or other forms of institutional acknowledgement (Bourdieu 1983: 190). The "about" and "über uns" sections of both SNS seem to provide a good opportunity to provide selected information about education. As an example, Company 8 lists that it offers the services of a "Microsoft Certified Technical Specialist [...]".

Language abilities are direct indicators of cultural capital (Bourdieu 1983; Bourdieu 1991). As an example, Company 3 explicitly mentions "competence in German-Danish language and culture."

We define company size, number of employees on SNS and followers/subscribers on the SNS as indicators of social capital. According to a Bourdieusian reading, these aspects offer clues to the number of members (or at least affiliations) in each group initiated by the company (Bourdieu 1983: 194) and how interesting the group is to potential clients.

Table 2: Indicators of capital on company profiles

\begin{tabular}{|c|c|c|c|}
\hline $\begin{array}{c}\text { Indicators of cultural } \\
\text { capital }\end{array}$ & Example & $\begin{array}{l}\text { Indicators of social } \\
\text { capital }\end{array}$ & Example \\
\hline Education & $\begin{array}{l}\text { Certificates } \quad \text { and } \\
\text { awards }\end{array}$ & Company size & 1-10 employees \\
\hline \multirow[t]{2}{*}{ Language abilities } & German & $\begin{array}{l}\text { Employees } \\
\text { represented on SNS }\end{array}$ & 1 employee \\
\hline & & Subscribers on SNS & 5 subscribers \\
\hline
\end{tabular}

With respect to the personal-professional profiles, we select education, language abilities and activities and interests as indicators of cultural capital. Unlike companies, HEs have the ability to display their interests and all types of activities. This category only seems to be personal and individualized because only certain interests and activities are presentable in a business context. However, such information may be more revealing than other categories in terms of cultural capital because it is predefined not 


\section{C ommunication \& Language at Work}

by institutions but instead by the HE's own use of time (Bourdieu 1983: 186). For social capital, we classify professional experience, groups and organizations, recommendations and contacts as indicators. Professional experience might point to group membership and beneficial work-related relationships, groups and organizations are nearly a synonym for social capital, and recommendations indicate that acquaintances or coworkers are willing to invest time and personal vouching and, thus, to lend credibility to an individual's qualification. The number of contacts on the SNS might not be significant with respect to how useful and valuable these contacts will be in non-virtual contexts. However, in an SNS context, a high number of contacts can be considered an asset per se; thus, we see it as an effective indicator.

Table 3: Indicators of capital in personal-professional profiles

\begin{tabular}{|c|c|c|c|}
\hline $\begin{array}{l}\text { Indicators of cultural } \\
\text { capital }\end{array}$ & Example & $\begin{array}{l}\text { Indicators of social } \\
\text { capital }\end{array}$ & Example \\
\hline Education & Master of Science & $\begin{array}{l}\text { Professional } \\
\text { experience }\end{array}$ & Years, title, company \\
\hline Language abilities & German & $\begin{array}{ll}\text { Groups } & \text { and } \\
\text { organizations } & \end{array}$ & Network Denmark \\
\hline \multirow[t]{2}{*}{$\begin{array}{l}\text { Activities and } \\
\text { interests }\end{array}$} & Sports & Recommendations & $\begin{array}{l}\text { Recommendations by } \\
\text { clients or coworkers }\end{array}$ \\
\hline & & Contacts & $500+$ contacts \\
\hline
\end{tabular}

All of the indicators are used as categories for quantitative and qualitative analysis. As recommended, we conducted pre-testing with 12 profiles selected from our own data (Merten 1995: 325) to ensure that the categories could be coded. This provided us the opportunity to control our categories and to first identify needs for further qualitative analysis. We used the inter-coder approach to pre-test reliability and validity (Früh 1991). The authors of this study independently assigned the same examples to the categories. 
C ommunication \& Language at Work

\section{Results}

\section{Quantitative Analysis of Company and Manager Profiles}

The quantitative comparative analysis of the company profiles shows that companies demonstrate more cultural capital on XING, whereas they demonstrate more social capital on LinkedIn (table 4). In particular, education is described more frequently on XING than on LinkedIn. The social-capital analysis reveals the "home" SNS of the companies: The LinkedIn profiles display a much higher number of employees and subscribers.

Table 4: Forms of capital displayed on company profiles on XING and LinkedIn (in \%)

\begin{tabular}{|l|l|c|c|}
\hline \multicolumn{1}{|c|}{ Form of capital } & \multicolumn{1}{|c}{ Category } & XING $(\mathrm{n}=17)$ & LinkedIn (n=17) \\
\hline Cultural capital & Education & 35.3 & 17.6 \\
\hline Cultural capital & Language abilities & 35.3 & 35.3 \\
\hline Social capital & Company size & 100 & 100 \\
\hline Social capital & Employees represented on & $0-10=82.3$ & $0-10=35.3$ \\
& SNS & $11-49=11.8$ & $11-49=35.3$ \\
& & $50<=5.9$ & $50<=529.4$ \\
& Subscribers & $0-10=6.5$ & $0-10=5.9$ \\
\hline Social capital & & $11-49=17.6$ & $11-49=29.4$ \\
& & $50<=5.9$ & $50<=64.7$ \\
\hline
\end{tabular}

The results obtained from the quantitative analysis of the manager profiles paint a similar picture. It can be seen from table 5 that the managers list more cultural capitalrelevant aspects on XING and more social capital-relevant aspects on LinkedIn. Although education is more frequently described on LinkedIn, language abilities and activities and interests described on XING outnumber those described on LinkedIn. Gathering and displaying social capital seem to be more efficacious on LinkedIn, which shows a higher frequency of groups and organizations and an exclusive use of the category of recommendations. Most noticeable, however, is the much higher number of direct contacts on LinkedIn. 
C ommunication \& Language at Work

Table 5: Forms of capital displayed on manager profiles on XING and LinkedIn (in \%)

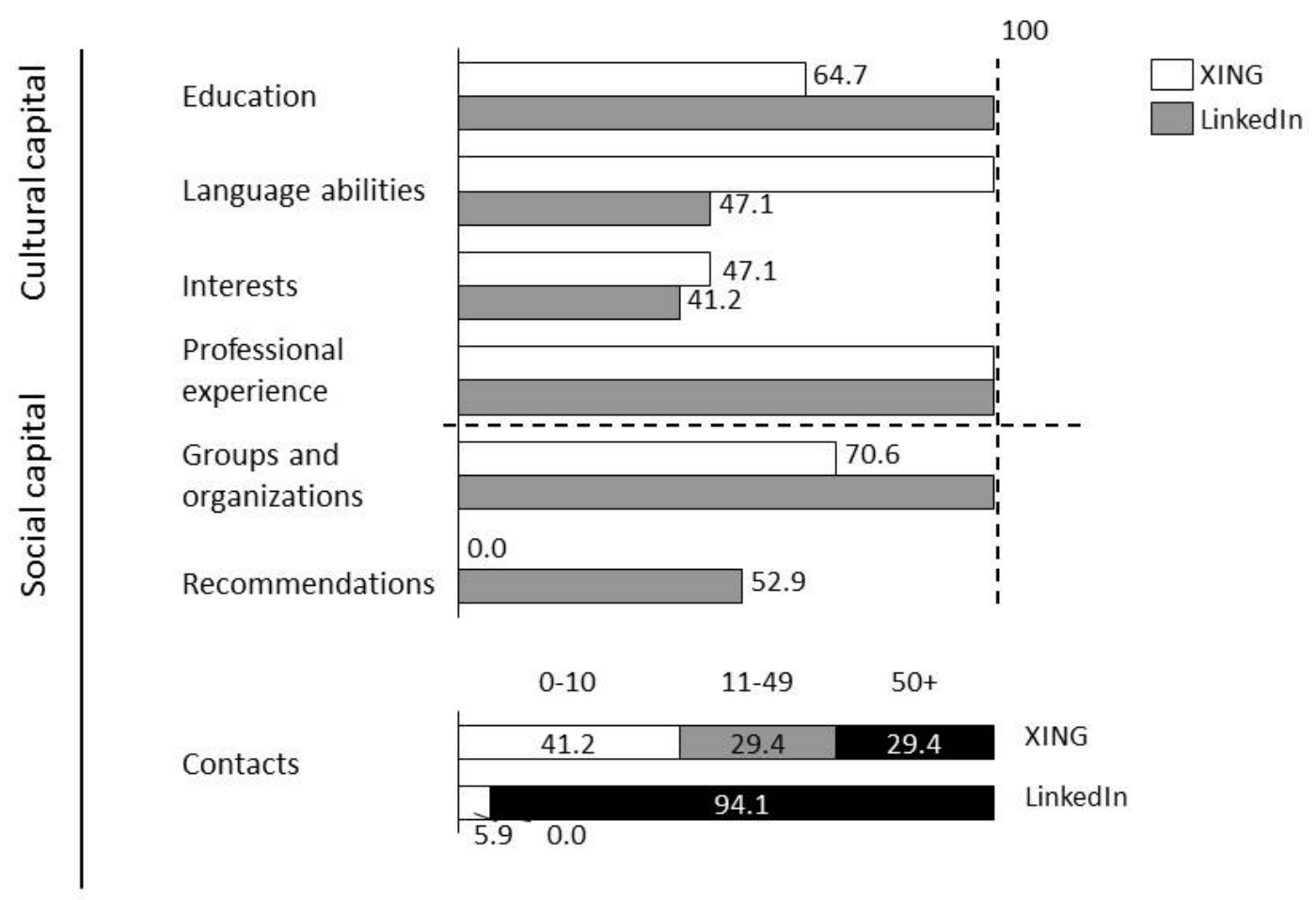

\section{Qualitative Analysis of Company and Manager Profiles}

Again, the most striking result obtained from the data is that both companies and managers display more cultural capital (particularly language abilities) on XING while displaying more social capital (particularly contacts and subscribers) on LinkedIn, even though they target the German market represented by XING. In the following section, we provide the results of a deeper qualitative analysis.

\section{Company profiles: cultural capital}

Qualitative analysis confirms that cultural capital is more pronounced on XING, primarily due to an emphasis on language ability. As an example, Company 11 (IT) emphasizes the category education, which is not mentioned at all on LinkedIn. Strongly connected to this category and to the description of the company's educational background in the form of institutionalized cultural capital is symbolic capital (Vgl. 


\section{C ommunication \& Language at Work}

Bourdieu 1976: 335ff.), in particular, honor and prestige (Vgl. Bourdieu 1976: 348). Symbolic capital is expressed through the mention of certificates and awards within a single text unit. The reputation of the award sponsors is emphasized by explicitly naming them (e.g., the Massachusetts Institute of Technology, BMW). Social and symbolic capital lead to institutionalized cultural capital in the form of a company's description as, e.g., a "gold-certified Microsoft and mySAP Service partner" (translated from the original German by the authors). Other companies also present their certifications exclusively under education on XING ("Microsoft-certified technical specialist," Company 8; "certified in several personality tests," Company 10 (translated from the original German by the authors)).

Only two companies use the same wording in the category education on both SNS. Interestingly, this is seen both in Danish (LinkedIn) and in German (XING). Generally, however, the descriptions vary and have no recognizable pattern.

The qualitative analysis provides further insight into the patterns underlying the quantitative analysis, resulting in a new category: currentness of data. One of the reasons that a few XING profiles fall short in the category of education may be that the LinkedIn profiles are much more up-to-date. This partly explains the mismatches between SNS profiles. One company lists seven awards on LinkedIn but only four on XING, apparently because it neglected to update its XING profile. We argue that leaving awards and prizes unlisted is detrimental to companies, particularly in the German market, because awards can be classified as institutionalized cultural capital that is immediately turned into symbolic capital through the power of institutional legitimization. The view that prizes and awards in a given field can function as cultural and symbolic capital and thus provide their bearers with credibility has been elaborated for the fields of journalism (Hanitzsch 2007: 243), literature (Ulmer 2006; Emmerich 2012: 22) and academia (Bourdieu 1988; McBride 2013; Wacquan 2013). Field-specific prizes serve as a means of distinction and consecration (Bourdieu 1998) insofar as they indicate the status, credibility and professionalism of a company in relation to its competitors. This is true in the fields of arts and culture, but it can be assumed that similar mechanisms work in other fields. Although Germany is similar to Denmark in terms of wealth, it is a slightly more stratified society (Hradil 2006; Mau and Verwiebe 


\section{C ommunication \& Language at Work}

2009; Schäfers 2012) in which distinction is more prevalent than it is in Scandinavia, which has national cultures strongly associated with the notion and idea of equality (Gullestad 1992; Bruun, Jakobsen et al. 2011). Thus, it might be advisable to mention awards, prizes and other merits in the German business context.

In analyzing language abilities, we derived another new category during the process of qualitative review. Because many companies highlight their language abilities, the need to control for correct use of the chosen language-whether English, Danish or German -was obvious. Out of all of the profiles noting language capabilities, only two minor mistakes could be identified: one in English, the other in German. Thus, this category had little informative value but was later applied to personal-professional profiles with more confirmatory results.

\section{Company profiles: social capital}

Quantitative analysis revealed that most companies succeed in having many employees represented on LinkedIn but fail to do so on XING. In terms of qualitative analysis, it is important to determine not only the number of employees but also what type (rank) of employee is represented. Similarly, we derived the new category visibility settings, which are important for accessing HE profiles, for gathering information about their names and functions and even for functioning as an extended "about us." Comparative analysis shows that mostly higher-ranking executives are represented on LinkedIn, whereas their number decreases on XING. Few lower-ranking employees are represented. As an example, Company 5 (legal consulting) presents only one higherranking executive on XING but several executives on LinkedIn, with the firm owner among them. Here again, knowledge of the German business culture demands a higher presence of HE. Social status, and thus symbolic capital, is affiliated with position and rank in Germany's organizational hierarchy (Wolf 1995; Kroeber-Riel and Weinberg 2003) as a result of income and education. Position and rank are common tools used to measure socio-economic status (Wolf 1995). To increase business credibility, companies should be able to present their HEs.

We observe a tendency to neglect the visibility function on XING. Although most CEO profiles are both openly accessible and connected to the company profile, on XING, this 


\title{
C ommunication \& Language at Work
}

is impossible in some cases. Occasionally, the CEO is not even listed in the company's employee network (e.g., Company 14, IT). Thus, a person who wants to contact the CEO needs to know the CEO's name in advance, may not be allowed to access the profile or, may be forced to leave the SNS to research the company website or search for further information on the Internet.

Similarly, qualitative analysis of the category subscribers on the SNS shows a higher business potential and more extended use of LinkedIn than of XING. Typically, LinkedIn subscribers are located in Denmark and thus are potential customers on the Danish side of the market. Conversely, nearly all of the companies lack potential German clients in their XING networks. Some companies have no German subscribers at all; nearly all of the companies have fewer German than Danish subscribers.

\section{Manager profiles: cultural capital}

Analysis of the category education documents a tendency to describe educational pathways in a more detailed and elaborate way on LinkedIn than on XING. Thus, even when information in this category is provided on both SNS - which is not always the case (s. table 5) — quality and informational content differ. Only two managers display a description that uses similar wording and lists the same biographical details. Six of the profile comparisons show a visibly more extensive presentation. A classic example is manager H (IT, Company 8), who provides different overviews of his educational achievements:

\footnotetext{
"Mechanical Engineer; Diploma in Specialized Business Studies" $[X I N G]$
}

\begin{abstract}
"Microsoft - Microsoft Certified Technology Specialist in NAV 2009 Manufacturing; DIEU - IT Governance; IBM IBM Project Management; IBM - IBM Marketing School; Aarhus Teknikum, Handelsskole, etc. - Mechanical Engineer studies [LinkedIn]
\end{abstract}

Those managers (2) who elaborate more extensively on aspects of their education on XING than they do on LinkedIn are in the minority. With respect to the display of 


\section{C ommunication \& Language at Work}

cultural capital, this might be an oversight: Recently, the Danish government has suggested increasing HE enrollments and graduations by $60 \%$ per year (Ministeriet for Forskning 2013). In comparison, high school graduation in Germany is much lower, at 33.9\% per year (Bildungsberichterstattung 2012). Furthermore, participation in higher education remains socially stratified, with a participation bias toward the (upper) middle classes (Isserstedt, Middendorff et al. 2010). Because "the distinctive power of cultural possessions or practices [...] tends to decline with the growth in the absolute number of people able to appropriate them" (Bourdieu 1984: 227), it can be assumed that education, particularly degrees and other institutional merits, serve as marks of distinction in Germany more than they do in Denmark. Mentioning such biographical data would therefore be beneficial in a German context.

There were two interesting results associated with the category of language ability. First, 11 managers indicate German language abilities in their profiles, but only seven profiles are written in German. Thus, we must emphasize the four who wrote their profiles in English despite having made their German language capabilities explicit. This is not the case for the LinkedIn profiles: not one manager decided to design a Danish-language profile; all of the profiles are written in English. The success of this strategy may be limited: The self-ascription of foreign-language capabilities is lower in Germany than in Denmark, where $66 \%$ of citizens attribute conversational skills in three languages to themselves (Germany: 27\%) (Commission 2006: 9). Although English and French are used to conduct intercultural business, in some fields, the tendency to see German as a "legitimate language" (Bourdieu 1991: 69) prevails. A relative lack of English practice might lead to skepticism and defensive demeanors, such as the attitude in some contexts that "the non-conversant converse in English" (Endres 2007, translated from the original German, the authors). English, especially English loanwords, can encounter some opposition and even-bizarrely_political intervention (Clyne 1995: 206; mmq/dapd 2010).

Second, manager profiles on XING were shown to contain more linguistic mistakes than those on LinkedIn. Seven XING profiles and only one LinkedIn profile display linguistic mistakes. Typically, these mistakes do not hinder basic understanding; e.g., they involve conjugating a verb incorrectly. Again, the mistake ratio is different on 


\title{
C ommunication \& Language at Work
}

LinkedIn: Almost all managers who list English (that is, the profile's language) as a competence use accurate language. Only one manager made a mistake, which was clearly a typographical error ("solicitor in corporate fiance [sic]," manager D).

The category activities and interests can be subdivided into three categories: 1) leisure activities, 2) professional skills and interests, and 3) mixed activities. On both XING and LinkedIn, few (and almost the same number of) managers (4 and 3) describe interests such as skiing, inline skating, marathon running or kayaking. However, it is evident that the descriptions on LinkedIn are much more wordy and elaborate than those on XING. Whereas leisure activities are most often simply listed on XING, the display on LinkedIn often has a storytelling structure. Manager $\mathrm{P}$ introduces his interests embedded in narrative phrases:

\begin{abstract}
"When time permits, I enjoy many sporting activities for the most running - completed a marathon in 2010, kayak, fitness training and football, but during the last couple of years, diving and golf have taken up more and more of my time especially on holidays. I have for several years been a Semi-Prof. football coach and consultant for both youth and adults." (Manager P [LinkedIn])
\end{abstract}

Similarly, professional skills and interests (such as private equity, wind energy and business analytics) are shown by only a few managers on XING and LinkedIn (3 and 2). In this case, the list form dominates both platforms. Finally, activities in a mixed form are described by one manager on XING and two managers on LinkedIn. In those cases, such different interests as "chess" and "business strategy" or "my family" and "the economy" are listed together. Mentioning social skills, interests and activities as an "essential part" of the European Union CV differs slightly from common German practice (Bostick and Wiehager 2005: 10; Center for the Development of Vocational Training 2014). This emphasis on indirectly job-related skills and activities might not have always been the case. Thus, a bit of reservation is appropriate-XING remains a platform for professional presentation, and like on a job application or $\mathrm{CV}$, the impression that one has more hobbies than work time should be avoided (Wolff 2012). At the same time, this section provides the opportunity to demonstrate social and cultural capital: According to Hartmann (Hartmann 2002), who investigated the social 


\section{C ommunication \& Language at Work}

origin and habitus of top German management, distinctive and decisive characteristics for professional success include, inter alia, a broad general education, adequate manners and social sovereignty in the field and entrepreneurial optimism. Knowledge of the professional field might provide guidance regarding decisions about what activities to mention.

\section{Manager profiles: social capital}

Quantitative analysis showed that all managers present their professional experience on both SNS. However, closer inspection of how this information is presented reveals that the information provided on LinkedIn is more detailed and seems to be more carefully arranged. This difference can be observed in the profile of manager $\mathrm{H}$, who presents himself solely as an "owner" of Company 8 on XING. In contrast, the description on LinkedIn not only is more detailed but also follows a slightly more narrative style and provides additional information:

\footnotetext{
"Founder and owner [Company 8, the authors]. [Company 8] is serving companies with manufacturing and logistics expertise based on Microsoft Dynamics NAVision [...]; Group ITManager [...]. IT management \& operations disciplines [...]" (Manager H, LinkedIn).
}

The category groups and organizations is more lively on LinkedIn. Most managers (16) on LinkedIn choose membership in groups that connect them to potential Danish clients. We examined the groups with respect to their connectedness and meaningfulness to the managers' profession and business, that is, a computer software company would meaningfully engage in a group called "internationalization for IT and gaming companies" (translated from the original Danish by the authors). On XING, group affiliation is a bit lower overall and seems to be slightly more random. We emphasize the importance of group belonging from a Bourdieusian perspective: It can provide valuable resources and "the backing of the collectivity-owned capital" (Bourdieu 1997). The more rare and prestigious a group is, the higher the symbolic 


\section{C ommunication \& Language at Work}

profit is. The credibility transferred from the group to the group member might be useful for impression management with respect to potential clients.

The most essential difference between the maintenance and use of the two SNS can be detected in the category of recommendations. This category is entirely missing from XING. In contrast, nine managers on LinkedIn display (sometimes several) recommendations. These recommendations can be subdivided into recommendations from Danish clients (4) and recommendations written by coworkers and managers (6). Interestingly for the impression management context, a recommendation written by a German coworker in German can be found among the latter. The question arises of why this recommendation is not used in the obviously suitable German XING context.

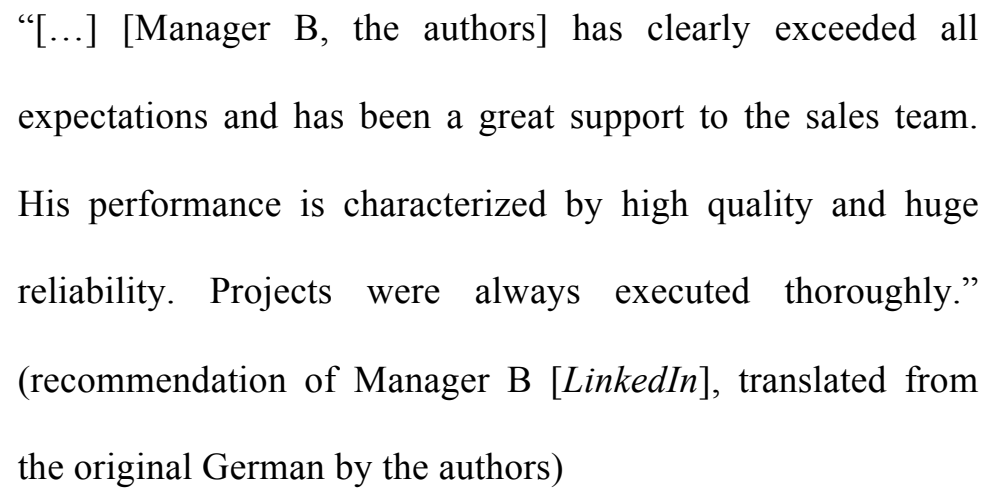

Consistent with the previous results, the quality of social contacts on LinkedIn is higher than on XING. The number of contacts on LinkedIn not only often greatly exceeds the number of contacts on XING but also seems to be of higher relevance. We searched LinkedIn contacts for decision-makers that could initiate or foster customer-client relations and found the strong presence of Danish CEOs among most LinkedIn contacts. This was not the case when observing XING. Our efforts were initially hindered by the decision of three XING users to restrict the visibility of their contacts. However, those same people's contacts could be accessed without restriction on LinkedIn. Given the very low number (the number of contacts is usually visible by default) of contacts on XING, this decision seems puzzling. A typical example of such a contact pattern would be manager A: He has 358 contacts on LinkedIn, among them many potential Danish 


\section{C ommunication \& Language at Work}

clients or multiplicators, such as Danish CEOs in relevant lines of business. In contrast, he only has seven contacts on XING.

\section{Discussion}

This paper investigates differences in impression management on the two SNS XING and LinkedIn, which are used in two different national contexts. We contribute to both theory and practice: our results contribute to theory development within impression management and SNS research and enable draft recommendations for SNS users navigating between two cultural contexts.

\section{Contributions to Theory}

With respect to Bourdieu's concepts, we demonstrate that HEs, especially on XING, miss an opportunity for capital transformation. Although it can be assumed that companies and CEOs/HEs strive for more economic capital, social and cultural capital are not treated accordingly. We surmise that this failure stems from a lack of field knowledge and the ability to "recognize and comply with demands immanent in the field" (Bourdieu 1990: 58) because it primarily occurs in the XING context. Increasingly less detailed information, linguistic mistakes and outdated biographical data characterize the XING profiles, compared to the (mostly) far better-maintained LinkedIn profiles. This result is striking for three reasons. First, it poses the question of why (in general) the same people who maintain their profiles competently on LinkedIn exhibit less understanding of SNS necessities on XING. Second, it seems surprising that opportunities to display social and cultural capital suitable for the German market are not displayed even though the companies target the German market. The third surprising observation is that capital that is specifically suitable for the German market is displayed on LinkedIn instead of on XING. We argue that to collect symbolic capital and to gain recognition on the respective business markets, social and cultural capital must be displayed through the categories analyzed earlier. By conducting an analysis using Bourdieusian concepts, we contribute to the development of connectivity to social theory in the field of SNS and impression management beyond a Goffman-bound perspective. The use of Bourdieusian capital concepts enables the identification of clear 


\section{C ommunication \& Language at Work}

indicators and categories on SNS profiles and allows for a structured comparative analysis.

\section{Contribution to Practice: Recommendations}

We conjecture that for experts in the German business market - and perhaps even in the cultural field-improving SNS-related impression management is a necessity.

We thus develop the following recommendations in relation to managers and companies' forms of capital.

For company profiles in general, we document an overall mismatch between the presentations on the two SNS. Although the profiles could display cultural sensitivity and could be adjusted to special cultural business practices because they are used in different cultural contexts, we believe that a first useful step would be to match the profiles to one another. Primarily, the XING profiles would benefit from adjustment to the data displayed on LinkedIn. Thus, we suggest the following:

\section{Companies should align the information presented on both of their SNS profiles.}

We have previously provided a summary of the importance of cultural capital, paying specific attention to the categories of education (which includes institutionalized proof of qualifications, certifications, diplomas, etc.) and language abilities. The display and accuracy of information about these aspects could be improved on both SNS to gain the trust and the respect that accompany embodied and institutionalized cultural capital (Bourdieu 1982: 212). This is particularly applicable to company profiles on XING, where German proficiency might be a valuable form of capital. We thus recommend the following:

\section{Companies should always list and elaborate on educational background information and language abilities.}

Furthermore, our analysis revealed mismatches between the indicated number of employees of companies and the actual number of employees represented on the SNS. Again, this is particularly pertinent to XING. We argue that a high number of represented employees connotes valuable social capital and thus trustworthiness 


\section{C ommunication \& Language at Work}

(Bourdieu 1997) to potential clients. With respect to the range of positions of employees listed on the SNS, we especially note the absence of HEs and CEOs, whose impression management is of special importance to the company (Pollach and Kerbler 2011). To mediate the impression of corporate unity, this omission should be avoided. We thus suggest the following:

3. Companies should encourage their employees, especially HEs, to maintain a profile on the respective SNS.

3a. Companies should encourage their employees to connect their profiles to their company profiles.

Social capital can be actively acquired on SNS. There is no need to wait for subscribers. Instead, it is possible to create a primary and secondary network of contacts. HEs could encourage members of their groups to subscribe, thus accumulating existing social capital. In short, an SNS' full potential lies in its several layers of contacts, and companies should make use of this feature in every way possible. Thus, we suggest the following:

\section{Companies should encourage clients and contacts to subscribe to their} profiles.

With respect to manager profiles, we have elaborated on how the categories of education, language abilities and interests are recognized by HEs as cultural capital in the field of business (Bourdieu 1982: 212). Additionally, we explained that managers' capital can potentially be transformed into symbolic or economic capital (Bourdieu 1997) and that, in practice, the display of their competences can impact their companies' public image (Pollach and Kerbler 2011). We have shown how HEs fail to display important parts of their capital, especially on XING. When capital was displayed, it was presented only superficially; thus, HEs are missing an opportunity to gain trust and recognition-e.g., by not mentioning institutional merits. Specifically, with respect to language abilities, agents should thoroughly proofread their texts when listing German as a business-relevant competence. We therefore recommend the following: 
Communication \& Language at Work

5. Managers should display their educational background and achievements, their knowledge abilities and their interests on both SNS.

5a. Managers should, especially on XING, elaborate on the quality of their education, their language abilities and their interests.

5b. Managers should align the form and content of their profiles (especially with regard to language abilities).

With respect to social capital, we considered the categories of professional experience, groups and organizations, recommendations and contacts. We found that managers on XING display their experience both less frequently and in a less detailed way than they do on LinkedIn, and we conjecture that a weaker understanding of the field-i.e., the German market - might be the reason for this. This is of utmost importance because professional experience is directly interwoven with the number and quality of social contacts acquired: A list of former employers or own companies indicates the density of the HE's network of former co-workers, employees, superiors and so on. The understanding of the concept itself seems to exist: some managers display not only their board positions but also their current positions on LinkedIn, but not on XING. Consequently, we suggest the following:

\section{HEs should list all of their professional experience, especially on XING.}

Furthermore, our analysis showed that many managers abstained from joining groups and organizations, thereby missing out on the opportunity to increase their social capital. This finding relates exclusively to XING: On LinkedIn, all HEs demonstrate (often active) membership in groups and organizations. At the same time, HEs on LinkedIn have more social contacts. Assuming an interdependency between the number of contacts and group memberships, we strongly recommend the following:

\section{HEs should become active members of XING groups and organizations.}

Our LinkedIn group displays recommendations from other SNS members, whereas the XING group does not. Accordingly, HEs lose an opportunity to demonstrate and provide support for their experience, which is of particular importance in the German market. In the managers' LinkedIn profiles, we observed recommendations, but they 


\section{C ommunication \& Language at Work}

were usually written by coworkers instead of clients or superiors. On this basis, we formulate our next recommendation:

\section{HEs should encourage contacts, especially clients, to provide recommendations.}

The two aforementioned recommendations lead to the category of contacts that managers display on the SNS. The number of contacts is most likely the most striking visualization of social capital on an SNS and thus is of special value: to transfer social into economic capital, HEs must display credible and honorable group membership (Bourdieu 1983: 195). Although group membership can be somewhat abstract, if the viewer is not in the group, a list of direct contacts provides credibility, or symbolic capital (Bourdieu 1976: 335ff). We have shown that even HEs who emphasize their German language abilities and their interest in the German market fail to collect social capital in the form of XING contacts, even when they display German contacts on LinkedIn. We thus call attention to the following:

\section{HEs should increase their number of social contacts on XING.}

\section{Limitations and Future Research}

A few of this study's limitations, along with directions for future research, should be noted. There are clearly many interesting aspects of SNS use and potential that could trigger the interest of researchers and practitioners for years to come. Given the up-todateness and fast development of the topic, it is clear that several gaps in this research need to be addressed.

First, this project was based on the axiomatic assumption that HEs and companies maintain SNS profiles to maximize profit and thus to accumulate economic capital. This assumption is essential for the application of the capital transformation concept. Researchers who differ in their perspective about this being the basic function from which other, more communicative functions unfold might find value in approaching SNS use from a different theoretical angle. Our assumption remains unproven because we did not investigate the impact of impression management on the revenues of the companies involved. Such a measurement would be a challenging (although highly relevant) task; future research might examine how such a project could be undertaken. 


\section{C ommunication \& Language at Work}

A different approach to this issue would add to our qualitative methods: Theory-guided and semi-structured face-to-face interviews with managers could reveal their subjective motives for using SNS.

To further investigate the question of why HEs successfully target one market on one SNS but neglect to do so on another SNS might be fruitfully investigated using a different concept beyond the Bourdieusian field correspondence, the "doxa" (Bourdieu 1990: 68). Hofstedian cultural dimensions (2005) may help to explain differences in managers' assessment of the importance of displaying certain biographical aspects for impression management. Such a stance is justifiable in the sense that the German and Danish business cultures seem to differ on a Hofstedian scale (s. e.g., "power distance", 2005: 59) and the display of status symbols, merits and privileges might be more popular in the more stratified German context (Oesch 2006; Oesch 2006b) than in a Scandinavian context, from which the notion of egalitarian individualism arose (s. Bruun, Jakobsen et al. 2011; Linnet 2011). However, such a theoretical extension would require an elaboration of the comparativeness of Bourdieusian "constructivist structuralism" (Bourdieu 1989: 14) and the relatively static Hofstedian dimensions.

In addition, limitations of the applied methods should be considered. Our sample is small but sufficient, considering our selection criteria. Our qualitative analysis faced challenges because not all contacts were made visible on XING and because those contacts were not visible by default in the absence of a contact on LinkedIn. With respect to the categories used for comparative analysis, it should be kept in mind that the two SNS do not offer the exact same functions. We only compared those functions that the two SNS have in common, but we must remember that overall, LinkedIn seems to offer more functions to its users. This increased functionality might lead to a higher willingness to provide more information in general and thus might be an additional reason for the better maintenance of LinkedIn profiles. 


\section{C ommunication \& Language at Work}

Moreover, it should be kept in mind that our observations are subject to change due to the general volatility of personal profiles on SNS and the fact that our research results have been communicated. We transmitted our results to the managers whose profiles we investigated and to a larger circle of managers in a regional manager association (Nielsen 2013). We thus expect that adjustments have been made to the profiles.

Finally, we note that attention should be given to the pictures and the format/layout displayed on XING and LinkedIn. A first and non-systematic observation reveals that the pictures displayed on both SNS are mostly identical and often show few formal dress codes and little standardization. We indicate that this might be another category to consider because different dress code expectations could be valid in the German market and adjustments might be beneficial to managers (Hartmann 2002). Accordingly, applying a multimodal perspective (Kress 2000; Kress 2010) might be fruitful: Multimodality allows for the involvement of all modes of communication, including pictures and the layout or chronology of displayed information. This perspective adds to the Bourdieusian approach (Lueg, Fage-Butler et al. 2014). It thus would be sensible to repeat this study one year later to apply the mentioned extensions and determine whether changes have been made.

\section{Conclusion}

In this investigation, the aim was to assess the differences in the use of two SNS targeting different national cultural markets. We approached this research objective by viewing the practices displayed on the two SNS through a Bourdieusian lens. Taken together, this study provides insights into companies' and managers' practices on SNS and how they might be improved to transform and increase existent forms of capital.

These findings suggest that in general, LinkedIn is used much more efficiently than XING. Considering the orientation of the selected companies and HEs toward the German market and given that XING is still a dominant SNS there, this asymmetric use is puzzling. Our analysis showed that in most categories, managers successfully display both social and cultural capital on LinkedIn but fail to do so on XING. Overall, the 


\section{C ommunication \& Language at Work}

results of this study indicate that impression management-from both a corporate perspective and a personal perspective-by companies and HEs could be improved. Thus, we have developed a set of recommendations for practitioners to align their profiles and to maximize their opportunities for capital transformation (s. contributions to practice). This is of high importance for companies that aim to successfully enter the German market or that seek to make the most efficient use of their SNS presentation. This research extends our knowledge of how SNS are used and shows that social media competence might not be the most important determinant of successful SNS use: Cultural knowledge, alignment and consistent maintenance also play important roles. By taking a Bourdieusian approach to the concepts of field and capital, this analysis improves upon the previous literature.

We hope to contribute to the understanding of the ways in which SNS are used and of their potential, and by applying a Bourdieusian perspective, we hope to add to the scope of theoretical approaches to the current research on SNS and impression management.

\section{References}

Bernardi, L., S. Keim, et al. (2007). "Social Influences on Fertility: A Comparative Mixed Methods Study in Eastern and Western Germany." Journal of Mixed Methods Research 1, 1, 23-47.

Bildungsberichterstattung, A. (2012). Bildung in Deutschland 2012. Ein indikatorengestützter Bericht mit einer Analyse zur kulturellen Bildung im Lebenslauf. B. f. B. u. Forschung. Bielefeld.

Bostick, H. and H.-J. Wiehager (2005). Erfolgreich bewerben mit dem europäischen Lebenslauf. Norderstedt.

Bourdieu, P. (1976). Entwurf einer Theorie der Praxis. Frankfurt am Main, Suhrkamp.

Bourdieu, P. (1977). Outline of a Theory of Practice. Cambridge, Cambridge University Press.

Bourdieu, P. (1982). Die feinen Unterschiede. Kritik der gesellschaftlichen Urteilskraft. Frankfurt am Main, Suhrkamp.

Bourdieu, P. (1983). Ökonomisches Kapital, kulturelles Kapital, soziales Kapital. Soziale Ungleichheiten. R. Kreckel. Göttingen, Otto Schwartz \& Co.: 183-198. 


\section{C ommunication \& Language at Work}

Bourdieu, P. (1984). Distinction: A Social Critique of the Judgement of Taste. Cambridge, Harvard University Press.

Bourdieu, P. (1988). Homo Academicus. Cambridge, Polity.

Bourdieu, P. (1989). "Social Space and Symbolic Power." Sociological Theory 7, 1, $14-$ 25.

Bourdieu, P. (1990). The Logic of Practice. Stanford, Stanford University Press.

Bourdieu, P. (1991). Language and Symbolic Power. Cambridge, MA, Harvard University Press.

Bourdieu, P. (1997). The Forms of Capital. Education, Culture, Economy, Society. A. H. Halsey, H. Lauder, P. Brown and A. S. Wells. Oxford, Oxford University Press: 46-58.

Bourdieu, P. (1998). Practical Reason: On the Theory of Action. Stanford, Stanford University Press.

Bourdieu, P. (2005). The Social Structures of the Economy. Cambridge, Polity Press.

Bourdieu, P. and J.-C. Passeron (1977). Reproduction in Education, Society and Culture. London, Sage.

Boyd, D. and J. Heer (2006). Profiles as Conversation: Networked Identity Performance on Friendster. Hawai'i International Conference on System Science, Kauai, IEEE Computer Society.

Boyd, D. M. and N. B. Ellison (2007). "Social Network Sites: Definition, History, and Scholarship." Journal of Computer-Mediated Communication 13, 1, 210-230.

Bruun, M. H., G. S. Jakobsen, et al. (2011). "IntroductIon: The Concern for SocialityPracticing Equality and Hierarchy in Denmark." Social Analysis 55, 2, 1-19.

Buffardi, L. E. and W. K. Campbell (2008). "Narcissism and Social Networking Web Sites." Personality and Social Psychology Bulletin 34, 10, 1303-1314.

Center for the Development of Vocational Training, C. (2014). "Europass. Download the $\mathrm{CV} \quad$ template and instructions." from http://europass.cedefop.europa.eu/en/documents/curriculum-vitae/templatesinstructions.

Clyne, M. (1995). The German language in a chaning Europe. Cambridge, Cambridge University Press.

Commission, E. (2006). Europeans and their languages. Special Eurobarometer. 


\section{Communication \& Language at Work}

Cunningham, C. (2013). Social networking and impression management: selfpresentation in the digital age. Lanham, Lexington Books.

Danmarks_Statistik (2013). "It-anvendelse i virksomheder 2013." Nyt fra Danmarks Statistik 460, 1-2.

Donath, J. and D. Boyd (2004). "Public Displays of Connection." BT Technology Journal 22, 4, 71-82.

Dwyer, C. (2007). "Digital Relationships in the 'MySpace' Generation: Results From a Qualitative Study. Pre-Publication Draft." Technical Report. Pace University. School of Computer Science and Information Systems 235, 1-10.

Ellison, N. B., C. Steinfield, et al. (2007). "The Benefits of Facebook "Friends:" Social Capital and College Students' Use of Online Social Network Sites." Journal of Computer-Mediated Communication 12, 4, 1143-1168.

Emmerich, W. (2012). "Konsekration und Kanonisierung. Tendenzen der Vergabe von Literaturpreisen in der Bundesrepublik 1950 bis 1989." Amsterdamer Beiträge zur neueren Germanistik 82, 1, 113-132.

Endres, H. (2007) "Jetzt mal Klartext." manager-magazin.de.

Früh, W. (1991). Inhaltsanalyse. Theorie und Praxis. . München, Ölschläger.

Goffman, E. (1976). Wir alle spielen Theater. Die Selbstdarstellung im Alltag. München, R. Pieper \& Co.

Good, K. D. (2013). "From scrapbook to Facebook: A history of personal media assemblage and archives." New Media \& Society 15, 4, 557-573.

Grasmuck, S., J. Martin, et al. (2009). "Ethno-Racial Identity Displays on Facebook." Journal of Computer-Mediated Communication 15, 1, 158-188.

Gullestad, M. (1992). The art of social relations: essays on culture, social action, and everyday life in modern Norway. Oslo, Scandinavian University Press.

Hanitzsch, T. (2007). Die Struktur des journalistischen Felds. Journalismustheorie: Next Generation. Soziologische Grundlegung und theoretische Innovation. K.-D. Altmeppen, T. Hanitzsch and C. Schlüter. Wiesbaden, VS: 239-260.

Hartmann, M. (2002). Der Mythos von den Leistungseliten. Spitzenkarrieren und soziale Herkunft in Wirtschaft, Politik, Justiz und Wissenschaft. Frankfurt/New York, Campus.

Hofstede, G. and J. G. Hofstede (2005). Cultures and Organizations. Software of the mind. New York, McGraw-Hill. 


\section{C ommunication \& Language at Work}

Hradil, S. (2006). Die Sozialstruktur Deutschlands im Internationalen Vergleich. Wiesbaden, VS.

Haas, B. and E. Scheibelhofer (1998). "Typenbildung in der qualitativen Sozialforschung. Eine methodologische Analyse anhand ausgewählter Beispiele." Reihe Soziologie 34, 1-25.

Isserstedt, W., E. Middendorff, et al. (2010). Die wirtschaftliche und soziale Lage der Studierenden in der Bundesrepublik Deutschland 2009. 19. Sozialerhebung des deutschen Studentenwerks durchgeführt durch HIS Hochschul-InformationsSystem. Bonn, Berlin BMBF.

Kieserling, A. (2008). "Felder und Klassen. Pierre Bourdieus Theorie der modernen Gesellschaft." Zeitschrift für Soziologie 37, 3-24.

Kress, G. (2000). "Multimodality: Challenges to Thinking about Language." TESOL Quarterly 34, 2, 337-340.

Kress, G. (2010). Multimodality: A Social Semiotic Approach to Contemporary Communication: Exploring Contemporary Methods of Communication, Routlegde.

Kroeber-Riel, W. and P. Weinberg (2003). Konsumentenverhalten, Vahlen.

LinkedIn (2013) "Number of users on linkedin." http://www.linkedin.com.

Linnet, J. T. (2011). "Money Can't Buy Me Hygge: Danish Middle-Class Consumption, Egalitarianism, and the Sanctity of Inner Space." Social Analysis 55, 2, 21-44.

Lueg, K. (2011). "Habitus in the Classroom: the Relevance of Student Heterogeneity and Departmental Culture for Learner-Oriented Didactics in Teaching Sociology." Journal of Social Science Education 10, 2, 29-38.

Lueg, K., A. Fage-Butler, et al. (2014). Knowledge asymmetries, internationalisation and signage: The aspirations of online documents and the reality of signs. Encompassing the Multimodality of Knowledge. Aarhus, Aarhus University, Research Group for Knowledge Communication.

Lueg, K. and R. Lueg (2015). "Why do students choose English as a medium of instruction? A Bourdieusian perspective on the study strategies of non-native English speakers." Academy of Management Learning and Education 14, 1.

Mau, S. and R. Verwiebe (2009). Die Sozialstruktur Europas. Konstanz, UVK.

Mayntz, R., K. Holm, et al. (1969). Einführung in die Methoden der empirischen Soziologie. Köln/Opladen, Westdeutscher Verlag. 
C ommunication \& Language at Work

Mayring, P. (1983). Qualitative Inhaltsanalyse. Grundlagen und Techniken. . Weinheim/Basel, Beltz.

Mayring, P. (2001). "Kombination und Integration qualitativer und quantitativer Analyse. ." Forum Qualitative Sozialforschung 2, 1, 1-14.

McBride, C. (2013). Recognition. Cambridge, Polity Press.

Merten, K. (1995). Inhaltsanalyse. Einführung in Theorie, Methode und Praxis. Opladen, Westdeutscher Verlag.

Ministeriet for Forskning, I. o. V. U. (2013). Politiske indsatser på uddannelsesområdet. Copenhagen.

mmq/dapd (2010). "Kampf gegen Anglizismen: Ramsauer feiert sich als Sprachpfleger." Spiegel online.

Nielsen, C. (2013). LinkedIn og Xing. Sådan får I og Jeres virksomhed vækst på det danske og tyske marked. Forskningsresultater og anbefalinger til optimering af Jeres person- og virksomhedsprofiler på LinkedIn og Xing. KonsulentNetSyd. Haderslev.

Nielsen, C. (2014). Impression-Management-Strategien. Eine komparative Analyse von den Impression-Management-Strategien dänischer Unternehmen und deren Manager auf den Social Network Sites xing und linkedin. Department of Business Communication. Aarhus, Aarhus University

Oesch, D. (2006). "Coming to Grips with a Changing Class Structure: An Analysis of Employment Stratification in Britain, Germany, Sweden and Switzerland." International Sociology 21, 2, 263-288.

Oesch, D. (2006b). Redrawing the Class Map: Stratification and Institutions in Britain, Germany, Sweden, and Switzerland. New York, Palgrave Macmillan.

Pollach, I. and E. Kerbler (2011). "Appearing Competent: A Study of Impression Management in U.S. and European CEO Profiles." Journal of Business Communication 48, 4, 355-372.

Rosen, D., P. R. Lafontaine, et al. (2011). "CouchSurfing: Belonging and trust in a globally cooperative online social network." New Media \& Society 13, 6, 981998.

Schäfers, B. (2012). Sozialstruktur und sozialer Wandel in Deutschland. Konstanz, UVK.

SID/FIT (2010 ) "Social Media Report 2010/11." 


\section{C ommunication \& Language at Work}

Stefanone, M. A., K. Kwon, et al. (2011). "The value of online friends. Netoworked resources via social network sites." First Monday 16, 2.

Tashakkori, A. (2009). "Are We There Yet?: The State of the Mixed Methods Community." Journal of Mixed Methods Research 3, 4, 287-291.

Udenrigsministeriet. (2014). "Økonomiske forhold i Tyskland." from http://tyskland.um.dk/da/om-tyskland/oekonomiske\%20forhold/.

Ulmer, J. S. (2006). Geschichte des Georg-Büchner-Preises: Soziologie eines Rituals, Walter de Gruyter.

Vester, H.-G. (1996). Kollektive Identitäten und Mentalitäten: Von der Völkerpsychologie zur kulturvergleichenden Soziologie und interkulturellen Kommunikation. Frankfurt am Main, IKO-Verlag für Interkulturelle Kommunikation.

Vitak, J. and N. B. Ellison (2013). "'There's a network out there you might as well tap': Exploring the benefits of and barriers to exchanging informational and supportbased resources on Facebook." New Media \& Society 15, 2, 243-259.

Wacquan, L. (2013). "Bourdieu 1993: A Case Study in

Scientific Consecration." Sociology 47, 1, 15-29.

Walther, J. B. and J.-w. Jang (2012). "Communication Processes in Participatory Websites." Journal of Computer-Mediated Communication 18, 1, 2-15.

Walther, J. B., B. Van Der Heide, et al. (2009). "Self-Generated Versus OtherGenerated Statements and Impressions in Computer-Mediated Communication: A Test of Warranting Theory Using Facebook." Communication Research 36, 2, 229-253.

Wolf, C. (1995). "Sozio-ökonomischer Status und berufliches Prestige: Ein kleines Kompendium sozialwissenschaftlicher Skalen auf Basis der beruflichen Stellung und Tätigkeit." ZUMA-Nachrichten 37, 102-136.

Wolff, V. (2012) "Hobbys im Lebenslauf. Bloß nicht übertreiben." Sueddeutsche.de.

Xing (2013) "Anzahl Nutzer auf Xing." http://corporate.xing.com. 


\section{First Author}

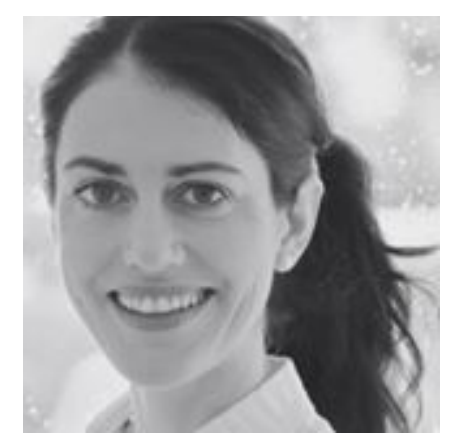

\section{Klarissa Lueg}

Assistant Professor, PhD, Department of Business Communication, Aarhus University

Klarissa Lueg is assistant professor at Aarhus University School of Business and Social Sciences. She holds a PhD in sociology from the University of Technology Darmstadt. Her current research centers on internationalization and sociocultural diversity in higher education. Her work appeared in Academy of Management, Learning and Education; Studies in Higher Education; Journal of Social Science Education; and Race, Gender, and Class.

\section{Contact:}

lueg@bcom.au.dk

Aarhus University

School of Business and Social Sciences

Department of Business Communication

Jens Chr. Skous Vej 4

8000 Aarhus C - Denmark

$\mathrm{T}:++4587165463$

\section{Second Author}

\section{Camilla Nielsen}

Post graduate

Camilla Nielsen is post graduate with excellent results from Aarhus University, School of Business and Social Sciences. She is currently pursuing her research interest in parallel to her work as a communication professional within marketing - both in a Danish and, in particular, a German context

\section{Contact:}

